\title{
Customer Switching Behavior dalam Membeli Batik dari UKM
}

\author{
Intan Permana \\ Fakultas Kewirausahaan, Universitas Garut \\ Jalan Jati 42 B Garut, 44151, Indonesia \\ intan@uniga.ac.id
}

\begin{abstract}
Abstrak- Tujuan penelitian ini adalah untuk menganalisis customer switching behavior dalam membeli batik dari UKM . Desain penelitian ini adalah cross sectional, menggunakan pendekatan deskriptif dengan metode explanatory survei. Unit analisis konsumen sebanyak 106 orang. Pengumpulan data dengan menggunakan kuesioner. Teknik analisis yang digunakan adalah teknik deskriptif dengan menggunakan distribusi frekuensi. Berdasarkan hasil penelitian menggunakan analisis deskriptif, didapatkan hasil bahwa customer switching behavior berkatagori baik. Perbedaan penelitian ini dengan penelitian sebelumnya adalah terletak pada variabel independen, yaitu layanan purna jual pada produk otomotif, serta menggunakan teori atau referensi yang berbeda dengan peneliti sebelumnya.
\end{abstract}

Kata Kunci- Customer switching behavior.

\section{PENDAHULUAN}

Menjaga komitmen dengan pelanggan merupakan tantangan bagi suatu perusahaan. Pelanggan merupakan suatu kehidupan bagi suatu perusahaan, perusahaan akan melakukan segala cara untuk mendapatkan pelanggan dan mempertahannkannya untuk kelangsungan hidup suatu bisnis. Strategi mempertahankan suatu pelanggan bukanlah hal yang mudah [1]. Kehilangan pelanggan merupakan suatu yang mustahil untuk membuat suatu perusahaan menciptakan nilai yang besar dalam hubungan dengan pelanggan [2]. Tidak peduli seberapa besar keunggulan pelayanan perusahaan yang diberikan setiap perusahaan akan sering membuat kesalahan ketika mencoba untuk memenuhi harapan pelanggan, itu akan menyebabkan pelanggan lebih menuntut dan rasa setia terhadap perusahaan berkurang [3]. Menjaga pelanggan untuk tetap setia pada suatu perusahaan bukanlah hal yang mudah untuk dijaga. Perusahaan akan memiliki pesaing dalam dunia bisnis. Pesaing dalam dunia pemasaran adalah salah satu yang harus difikirkan oleh perusahaan [4]. Persaingan menjadi sengit ketika pesaing mengambil alih pelanggan setia kita [5]. Banyaknya perusahaan yang banyak di tawarkan di pasar mengakibatkan pelanggan akan beralih merek atau yang disebut "Customer Swtiching Behavior" [6]. Praktik customer swtiching behavior telah menjadi sebuah hal yang normal dalam pemasaran [7]. Mengontrol customer swtiching behavior suatu perusahaan harus menjaga pelanggan mereka [1]. Fenomena customer swtiching behavior membuat suatu wawasan untuk sebuah perusahaan [8].

Penelitian pada bidang pemasaran menjelaskan bahwa studi tentang customer switching behavior suatu fenomena yang sering muncul di masyarakat [9]. ustomer orientation, competitor orientation, dan customer satisfaction dapat meningkatkan niat pada pelanggan untuk tetap bertahan pada suatu perusahaan [10]. Organisasi bisnis di pasar dinamis saat ini semakin berorientasi pada pelanggan, yang mewujudkan pentingnya menjaga hubungan pelanggan dalam jangka panjang. Konsep consumer switching behavior memperoleh perhatian yang cukup besar sejak dekade terakhir. Mempertahankan pelanggan saat ini, penting bagi perusahaan untuk memahami mengapa pelanggan beralih pada perusahaan lain [11]. Penelitian pada customer switching behavior dilakukan pertama kali oleh Keaveney pada tahun 1995 [12]. Menurutnya pelanggan dapat menyebabkan menurunnya tingkat pendapatan suatu perusahaan [13]. Mengetahui dan memahami variabel yang mempengaruhi customer switching behavior juga penting bagi perusahaan [14].

Perilaku perpindahan pelanggan pada penelitian terdahulu ditemukan pada industri telekomunikasi yang berkaitan dengan penyedia provider yang memiliki banyak faktor yang berdampak pada perilaku perpindahan pelanggan [5]. Penelitian customer switching behavior pun ditemuka pada industri perhotelan (Dev, Zhou, Brown, \& Agarwal, 2009). Industri retail bank pun salah satu industri yang 
sering diteliti tentang customer switching behavior [11]. Fenomena customer switching behavior yang sering muncul di masyarakat mengacu kepada keputusan konsumen untuk membeli berbagai macam produk atau jasa yang berbeda [16]. Perpindahan pelanggan pada suatu perusahaan merupakan masalah yang harus diselesaikan oleh perusahaan karena pelanggan merupakan aset perusahaan dan aset untuk masa depan [17]. Perpindahan pelanggan pada perusahaan lain salah satu penyebabnya ialah tingginya biaya berpindah pada layanan lain yang dirasakan sendiri oleh pelanggan suatu perusahaan. [18]. Keputusan pelanggan untuk berpindah pada perusahaan lain karena mereka tidak puas pada hasil penawaran suatu perusahaan [19].

Komitmen pelanggan sangat penting didalam pemasaran, dengan terciptanya komitmen pelanggan maka para pemasar bisa mengharapkan dapat mempertahankan pelanggannya dalam jangka panjang, bahkan jika mungkin untuk selamanya. Pelanggan yang sudah berkomitmen pada sebuah produk atau jasa maka akan kecil kemungkinan melakukan perpindahan pelanggan [20]. Tuntutan konsumen sangat bervariasi dan persaingan pasar sangat parah, untuk memuaskan berbagai konsumen kebutuhan dan memperoleh keuntungan di pasar yang kompetitif, banyak perusahaan berniat mengenalkan yang terbaru dan terbaik layanan untuk mempertahankan pelanggan. Biaya peralihan merupakan strategi penting untuk mempertahankan pelanggan [21]. Beralihnya pelanggan pada perusahaan atau jasa lain mengalami penurunan akbiat perpindahan biaya [22]. Untuk sebuah perusahaan perpindahan biaya menjadi alasan penting untuk mempertahankan pelanggan tidak beralih pada perusahaan lain [23]. Perpindahan biaya hal yang penting dalam area pemasaran [22].

\section{KAJIAN PUSTAKA}

Customer switching behavior pertama kali dikemukakan oleh Susan M. Keaveney dalam penelitiannya yang berjudul Customer Switching Behavior in Service Industries: An Exploratory Study pada tahun 1995. Customers switching behavior ini penting dipahami oleh sebuah perusahaan jasa karena dapat memberikan dampak yang signifikan pada keberlangsungan masa depan sebuah perusahaan. Pasalnya, jika pengguna jasa melakukan perpindahan maka perusahaan akan kehilangan pelanggannya. Pada umumnya customers switching behavior erat kaitannya dengan ketidakpuasan pengguna terhadap jasa yang disediakan atau yang ditawarkan oleh penyedia jasa utama. Namun tingkat kepuasan saja sebenarnya tidak cukup untuk menjelaskan perpindahan yang terjadi, sehingga perlu faktor-faktor lain untuk menjelaskan perpindahan tersebut. Customer switching behavior adalah perilaku konsumen yang mencerminkan pergantian dari merek produk yang biasanya dikonsumsi dengan produk merek lain (Ganes, Arnold, Reynold, 2006). Keputusan konsumen untuk berpindah merek terjadi karena dipengaruhi oleh variety seeking, strategi keputusan (decision strategy), faktor situasional dan normatif, ketidakpuasan terhadap merek sebelumnya, dan strategi pemecahan masalah (problem solving strategy) (Hoyer dan Ridgway, 1984). Bansal, et al (2005:97) juga mendefinisikan customers switching behavior sebagai perpindahan yang dilakukan oleh pengguna suatu penyedia jasa kepada penyedia jasa lain. Customers switching behavior dapat disebut juga sebagai customers exit atau customers defection behavior yang dapat didefinisikan sebagai perilaku pengguna jasa yang meninggalkan penyedia jasa lamanya (Siddiqui, 2011:364).

Banyaknya penelitian yang telah dilakukan terhadap customers switching behavior membuktikan bahwa konsep ini memang sudah tidak asing lagi di dalam dunia pemasaran. Salah satu dimensi yang dikemukakan oleh [24] adalah

1. Intend adalah niat yang muncul dari konsumen untuk beralih ke penyedia layanan lain.

2. Need adalah keperluan yang dimiliki oleh konsumen untuk dipenuhi, hal ini dapat terjadi apabila kebutuhan dari konsumen tidak dapat dipenuhi oleh penyedia layanan sehingga dirasakan perlu untuk mencari penyedia layanan lain.

3. Disappointment adalah perasaan kecewa yang dialami oleh konsumen kepada penyedia layanan jasa terhadap pelayanan yang diberikan, sehingga menimbulkan perasaan kecewa kepada perusahaan.

Keputusan untuk berpindah dari merek satu ke merek lain merupakan fenomena kompleks yang dipengaruhi oleh faktor-faktor perilaku tertentu, skenario persaingan, dan waktu. Beralihnya pelanggan pada perusahaan lain memiliki beberapa faktor. Model yang dikembangkan oleh Ojan Karimii1, Mohammad Mahmoudi Maymand1, Mirza Hasan Hosseini1, dan Mostafa Ahmadinejad (2012) meneliti salah satunya yaitu "Switching Cost" yang dapat mengukur dengan biaya yang berasal dari perusahaan atau pesaing yang lainnya. Switching Cost akan berhubungan dengan beralihnya pelanggan yang sehubungan dengan uang. Pelanggan dapat beralih pada perusahaan lain karena ada biaya yang tinggi dengan membuat perubahan penyedia layanan bagi pelanggan. Switching Cost merupakan faktor yang dapat berpengaruh terhadap perilaku beralihnya pelanggan. Model yang dikembangkan oleh Ojan Karimii, Mohammad Mahmoudi Maymand1, Mirza Hasan Hosseini1, dan Mostafa Ahmadinejad (2012) Perusahaan tau bahwa mendapatkan pelanggan bukan berati memiliki pelanggan. Pentingnya 
layanan perusahaan dapat meningkatkan niat pelanggan untuk tetap tinggal dan loyal pada perushaaan [25]. Kehilangan pelanggan merupaka suatu tantangan untuk setiap perusahaan. Menjaga pelanggan lama terutama di pasar produk banyak sekali pesaingnya [26].

\section{HASIL PENELITIAN DAN PEMBAHASAN}

Tanggapan Pelanggan mengenai Customer Switching Behavior

Secara keseluruhan variabel customer switching behavior $(\mathrm{Y})$ yang terdiri dari intend $\left(\mathrm{Y}_{1}\right)$, need $\left(\mathrm{Y}_{2}\right)$, dan dissapoinment $\left(\mathrm{Y}_{3}\right)$ dapat diketahui kedudukannya berdasarkan skor yang didapat dari rekapitulasi data. Rekapitulasi ini dapat membantu dalam melihat sejauh mana tanggapan dari konsumen Batik UKM terhadap dimensi-dimensi yang ada, dapat dilihat pada Tabel 4.13 berikut.

\begin{tabular}{llccc}
\multicolumn{5}{c}{ TABEL 4.1 } \\
\multicolumn{5}{c}{ REKAPITULASI TANGGAPAN PELANGGAN } \\
\multicolumn{5}{c}{ MENGENAI } \\
\multicolumn{5}{c}{ CUSTOMER SWITCHING BEHAVIOR } \\
\hline \multirow{2}{*}{ No } & \multirow{2}{*}{ Dimensi } & Skor & Total & $\%$ \\
& & Ideal & Skor & \\
\hline \multirow{2}{*}{1} & Intend & $\mathbf{2 2 2 6}$ & $\mathbf{1 6 0 9}$ & $\mathbf{7 2 , 2 8}$ \\
2 & Need & $\mathbf{4 4 5 2}$ & $\mathbf{3 1 7 1}$ & $\mathbf{7 1 , 2 3}$ \\
3 & Dissapoinment & $\mathbf{4 4 5 2}$ & $\mathbf{2 9 9 4}$ & $\mathbf{6 7 , 2 5}$ \\
& TOTAL & $\mathbf{1 1 1 3 0}$ & $\mathbf{7 7 7 4}$ & $\mathbf{6 9 , 8 5}$ \\
\hline
\end{tabular}

Sumber: Hasil Pengolahan Data, 2018

Tabel 4.13 menjelaskan mengenai rekapitulasi skor dari dimensi-dimensi yang ada pada customer switching behavior. Besarnya skor yang dimiliki setiap dimensi tersebut dapat menjelaskan bahwa adanya customer switching behavior yang terjadi pada konsumen Batik dari UKM .

Customer switching behavior berdasarkan item pernyataan (indikator) menunjukkan bahwa nilai tertinggi berada pada dimensi intend sebesar 72,28\%. Menurut [24] niat seorang pelanggan untuk beralih dari satu penyedia layanan ke penyedia layanan lain, akan menghasilkan penurunan laba dari perusahaan. Perilaku perpindahan pelanggan membantu menciptakan hubungan antara konsumen dan produsen.

Sedangkan untuk dimensi dengan nilai terendah yaitu dimensi dissapoinment dengan perolehan 67,25\%. Pelanggan membangun niatnya untuk beralih dari satu penyedia layanan ke penyedia layanan lain jika kebutuhan mereka tidak terpenuhi. Perusahaan dapat meningkatkan kepuasan pelanggan dengan meningkatkan layanan yang mereka sediakan dengan produk atau layanan. Pergeseran perilaku membantu dalam membuat hubungan antara pelanggan dan perusahaan [24].

Skor ideal variabel customer switching cost sebesar 11130 untuk 15 item pernyataan. Perolehan skor berdasarkan hasil pengelolaan data pada variabel customer switching behavior adalah 7774 atau $69,85 \%$ dapat dikatakan bahwa sebagian besar responden menyatakan customer switching behavior pada pengguna layanan jasa internet dalam kategori tinggi.

Variabel customer switching behavior terdiri dari tiga dimensi dengan 15 indikator. Dimensi pertama yaitu intend dengan indikator attractiveness, awareness, dan concern. Dimensi kedua yaitu need dengan indikator capacity dan priority. Dimensi ketiga yaitu dissapoinment dengan indikator unexpected dan experience. Berdasarkan hasil penelitian dari kuesioner yang disebar kepada 106 responden dapat diketahui bahwa customer switching behavior konsumen Batik dari UKM mendapatkan skor 7774 atau $69,85 \%$, dari skor ideal yaitu 11130. Perolehan skor tersebut secara kontinum berada pada kategori cukup baik dengan interval antara 7028 dan 8395. Jika dilihat berdasarkan dimensi, dimensi intend mendapat persentase ketercapaian tertinggi dengan skor 1609 atau $72,28 \%$ dan dimensi need mendapat persentase ketercapaian terendah dengan tingkat skor 3171 atau $71,23 \%$. Jika dilihat berdasarkan indikator keseluruhan customer switching behavior, indikator yang mendapatkan skor tertinggi dengan pernyataan ketertarikan pelanggan terhadap penyedia layanan yang diberikan Batik dari UKM dengan perolehan skor 543 atau sebesar $73,18 \%$. Sedangkan indikator yang mendapatkan skor terendah dengan pernyataan seringnya ketidaksesuaian ekspektasi konsumen terhadap pelayanan produk tingkat pelanggan atau merek memiliki keinginan dan tujuan yang sama dengan perolehan skor 488 atau sebesar 65,77\%. Hasil penelitian menunjukkan bahwa intend (company characteristic) merupakan dimensi yang penting dalam menciptakan perilaku perpindahan pelanggan, niat seorang pelanggan untuk berpindah pada layanan jasa lainnya merupakan suatu kerugian bagi suatu perusahaan [24].

\section{KESIMPULAN}

Gambaran mengenai Customer Switching Behavior pada pelanggan Batik dari UKM di Bandung sebagian besar berada pada kategori cukup baik. Artinya pelanggan Batik dari UKM tidak akan beralih pada lainnya dan tetap bertahan pada Batik dari UKM. Dimensi yang memperoleh tanggapan paling tinggi 
adalah dimensi intend dan dimensi dengan perolehan tanggapan paling rendah adalah dissapoinment. variabel customer switching behavior walaupun kinerjanya sudah menunjukkan hasil yang cukup baik namun tingkat perilaku perpindahan pelanggan masih kuat. Hal ini berkenaan dengan respon pengguna mengenai dimensi dissapoinment yang mendapatkan tanggapan paling rendah yang berarti pelanggan merasa kecewa dengan produk dan layanan yang diberikan Batik dari UKM kepada pelanggan. Temuan ini sesuai dengan penelitian yang dilakukan oleh [27] bahwa kekecewaan yang dialami oleh konsumen dapat menjadi faktor akhir beralihnya konsumen kepada penyedia layanan lain. Kelemahan pada penelitian ini diantaranya adalah penelitian yang dilakukan pada satu waktu (cross sectional) sehingga ada kemungkinan perilaku individu yang cepat berubah dari waktu ke waktu, selain itu dalam penelitian ini hanya ada satu variabel yang digunakan untuk mengidentifikasi perilaku perpindahan pelanggan.

\section{REFERENSI}

[1] G. K. Sahi, R. Sambyal, and H. S. Sekhon, "Analyzing Customers' Switching Intentions in the Telecom Sector Analyzing Customers, Switching Intentions in the Telecom Sector ABSTRACT," vol. 1762, no. July, 2016.

[2] S. D. Alessandro, L. Johnson, D. M. Gray, and L. Carter, "Journal of Services Marketing," 2015.

[3] D. Nikbin, I. Ismail, M. Marimuthu, and H. Armesh, "Perceived justice in service recovery and switching intention," vol. 35, no. 3, pp. 309-325, 2012.

[4] V. Vyas, "Drivers of customers ' switching behaviour in Indian banking industry," vol. 32, no. 4, pp. 321-342, 2014.

[5] P. Srinuan, M. T. Annafari, and E. Bohlin, "An analysis of switching behavior in the Thai cellular market," 2011.

[6] M. Abdel, H. Saleh, A. Althonayan, A. Alhabib, and E. Alrasheedi, "Customer Satisfaction and Brand Switching Intention: A Study of Mobile Services in Saudi Arabia," vol. 3, no. 2, pp. 62-72, 2015.

[7] S. M. Keaveney, "Customer Switching Behavior in Online Services : An Exploratory Study of the Role of Selected Attitudinal, Behavioral, and Demographic Factors," no. Carl 1995, 2003.

[8] T. A. Burnham, J. K. Frels, and V. Mahajan, "Consumer switching costs : A typology, antecedents , and consequences," 2003.

[9] M. P. Kashyap and D. Bhattacharjee, "An Empirical Comparison of Brand Switching
Behaviour of Rural and Urban Consumer : A Markovian Approach," Int. Conf. Front. Math., pp. 108-112, 2015.

[10] S. Sampaothong, Z. Yingheng, H. Jiqin, and P. Punyawattoe, "The Brand Switching Analysis of Thai Rice in China: A Comparison with Vietnam," Int. J. Bus. Manag., vol. 4, no. 1, pp. 339-344, 2016.

[11] S. G. Nimako and M. Studies, "Consumer Switching Behaviour: A Theoretical Review and Research agenda," 2012.

[12] C. Yu, "Consumer Switching Behavior From Online," vol. 7, no. 1, pp. 1-28, 2014.

[13] A. Warokka and C. Gallato, "Do Customer Dissatisfaction and Variety Seeking Really Affect the Product Brand Switching ? A Lesson from the Biggest Southeast Asia Mobile Telecommunication Market," J. Mark. Res. Case Stud., vol. 2012, p. 14, 2012.

[14] Y.-F. C. Y.-F. Tai, "Membership-based consumer switching intentions and benefit exchange theory", International Journal of Contemporary Hospitality Management," Int. J. Contemp. Hosp. Manag., vol. 28, no. 7, 2016.

[15] C. Dev, K. Z. Zhou, J. Brown, and S. AgarwaL, "Customer Orientation or Competitor Orientation Payoff for Hotel Brands ? 1," vol. 50, no. 1, pp. 19-28, 2009.

[16] K. L. Ailawadi, S. A. Neslin, and K. Gedenk, "Pursuing the Value-Conscious Consumer : Store Brands Versus," pp. 71-89, 1998.

[17] R. B. Money, "Word-of-mouth promotion and switching behavior in Japanese and American business-to-business service clients," vol. 57, pp. 297-305, 2004.

[18] Rais Ahmad Itoo and A. A. Naik, "Communication And Promotion of Integrated Marketing," Mon. Multidiscip. Res. J., vol. III, no. Ii, pp. 1-3, 2013.

[19] G. Kaur, R. D. Sharma, and N. Mahajan, "Exploring customer switching intentions through relationship marketing paradigm," no. 1990, 2014.

[20] W. Nofriana, "Trust, Switching Cost dan Komitmen Pelanggan," pp. 1-9, 2014.

[21] S. Ting, "The Relationship between Customers' Switching Cost and Repurchase Intention : The Moderating Role of Satisfaction," no. August, pp. 313-322, 2014.

[22] Z. Pourabedin, Y. S. Foon, R. Subhra, and C. Jessica, "Customers' online channel switching behavior : The moderating role of switching cost," no. Jensen 2007, 2014.

[23] S. Minarti and W. Segoro, "The influence of customer satisfaction, switching cost and trusts in a brand on customer loyalty - the 
survey on student as im3 users in," Procedia Soc. Behav. Sci., vol. 143, pp. 1015-1019, 2014.

[24] K. Hussain and M. Rizwan, "Customer loyalty and switching behavior of customer for Pepsi in Pakistan," vol. 4, no. 2, pp. 129-145, 2014.

[25] S. M. Keaveney, "Customer Switching Behavior in Service Industries : An Exploratory Study," vol. 59, no. 2, pp. 71-82, 2013.

[26] O. Karimii, M. M. Maymand, M. H. Hosseini, and M. Ahmadinejad, "Customer Switching Behavior: Developing model in the Iranian Retail Banking Industry," vol. 2, no. 12, pp. 11984-11991, 2012.

[27] Y. Liu, "Modeling consumer switching behavior in social network games by exploring consumer cognitive dissonance and change experience," 2016. 